\title{
Het verrichten van diensten onder bezwarende titel als belastbaar feit in de omzetbelasting
}

Citation for published version (APA):

Stevens, D. M. P. M. (2001). Het verrichten van diensten onder bezwarende titel als belastbaar feit in de omzetbelasting. [Doctoral Thesis, Maastricht University]. D.M.P.M. Stevens.

https://doi.org/10.26481/dis.20010309ds

Document status and date:

Published: 01/01/2001

DOI:

$10.26481 /$ dis.20010309ds

Document Version:

Publisher's PDF, also known as Version of record

\section{Please check the document version of this publication:}

- A submitted manuscript is the version of the article upon submission and before peer-review. There can be important differences between the submitted version and the official published version of record.

People interested in the research are advised to contact the author for the final version of the publication, or visit the DOI to the publisher's website.

- The final author version and the galley proof are versions of the publication after peer review.

- The final published version features the final layout of the paper including the volume, issue and page numbers.

Link to publication

\footnotetext{
General rights rights.

- You may freely distribute the URL identifying the publication in the public portal. please follow below link for the End User Agreement:

www.umlib.nl/taverne-license

Take down policy

If you believe that this document breaches copyright please contact us at:

repository@maastrichtuniversity.nl

providing details and we will investigate your claim.
}

Copyright and moral rights for the publications made accessible in the public portal are retained by the authors and/or other copyright owners and it is a condition of accessing publications that users recognise and abide by the legal requirements associated with these

- Users may download and print one copy of any publication from the public portal for the purpose of private study or research.

- You may not further distribute the material or use it for any profit-making activity or commercial gain

If the publication is distributed under the terms of Article $25 \mathrm{fa}$ of the Dutch Copyright Act, indicated by the "Taverne" license above, 


\title{
STELLINGEN
}

\author{
behorend bij het procfschrift van D.M.P.M. Stevens \\ 'het verrichten van diensten onder bezwarende titel \\ als belastbaar feit in de omzetbelasting
}

1. De gedachte achter de uitzonderlijke positic van de landbouw in de omzetbelasting was dat deze sector niet zou kunnen voldoen aan de voor de heffing van de omzctbelasting gestelde administratieve verplichtingen. Deze gedachte is voor het moderne agrarische bedrijf niet meer houdbaar. De landbouwregeling in de omzetbelasting dient dientengevolge te worden geschrapt.

2. Het recht op aftrek van voorbclasting roals necrgelegd in de Wet op de omzetbelasting 1968 is nict in overeenstemming met de Zesde richtijn betreffende de harmonisatic van de wetgevingen der Lid-Staten inzake omzelbelasting - Gemeenschappelijk stelsel van belasting over de toegevoegde waardc: uniforme grondslag (77/388/EEG).

3. Sedert het Molnr-arrest on het Landboden Agrardienste-arrest is het duidelijk dat in geval van subsidicverlening en schadevergoedingen belastingheffing vaak achterwege dient te blijven wegens gebrek aan enig verbruik.

4. Om recht te doen aan het oorsprongslandbeginsel dient in de omzetbelasting vooralsnog uitvocring te worden gegeven aan het bestemmingslandbeginsel.

5. Indachtig de opmerking van K.V. Antal de Felsocgeller dat de belastingmoraal wegsmelt naarmate de tempcratuur stijgt, voorspelt het brocikaseffect niet veel gocds.

6. Bij de mens is de Iengte van de tenen recht evenredig aan de omvang van het cgo.

7. Hocwel de omzetbelasting in 1934 werd ingevoerd als een tijdelijke belasting is haar. dankzij haar hoge opbrengst. cen lang leven beschoren.

8. Alleen in het geval van een fiscale eenheid is onder de huidige omzctbelastingwetgeving sprake van een eigen kring tussen de van de fiscale cenheid decl uimakende ondernemers.

9. Hel feit dat de verlaging van de tarieven in de loon- en inkomstenbelasting en de introductic van de arbcidskorting voor 10 miljard gulden wordt gefinancierd uit grondslagverbredende matregelen in de inkomstenbelasting en voor 8 miljard gulden uil de verhoging van het standaard BTW-tarief van $17.5 \%$ naar $19 \%$ en de verhoging van de milicubelastingen, toont zowel in absolute als relatieve zin het vaak onderschattc - belang aan van dezc belastingen. 